\title{
The Relationship between Type 2 Diabetes Mellitus with Chronic Kidney Disease In Indonesian Population In 2014-2015 (Data Analysis of IFLS 5)
}

\section{Hubungan Diabetes Melitus Tipe-2 dengan Penyakit Ginjal Kronis pada Penduduk Indonesia Tahun 2014-2015 (Analisis Data IFLS 5)}

\author{
Tri Damayanti Simanjuntak ${ }^{\mathrm{a}^{*}}$, Tri Yunis Miko Wahyono ${ }^{\mathrm{b}}$ \\ ${ }^{a}{ }^{*}$ Magister Prodi Epidemiologi Fakultas Kesehatan Masyarakat Universitas Indonesia, Lantai 1 Gedung A, Kampus UI Depok, Indonesia \\ ${ }^{\mathrm{b}}$ Departemen Epidemiologi, Fakultas Kesehatan Masyarakat Universitas Indonesia, Lantai 1 Gedung A, Kampus UI Depok, Indonesia
}

A B S T R A K

Penelitian Global Burden of Disease pada tahun 2010 mengungkapkan bahwa kasus penyakit ginjal kronis mengalami peningkatan dan menjadi masalah kesehatan serius. Data Riskesdas tahun 2013 mengungkapkan bahwa proporsi penderita gagal ginjal kronis usia $\geq 15$ tahun berdasarkan diagnosis dokter sebesar $0,2 \%$ dan $0,6 \%$. Penelitian ini bertujuan menganalisis hubungan diabetes mellitus tipe 2 dan penyakit ginjal kronis pada penduduk di Indonesia. Desain penelitian ini adalah crosssectional dan menggunakan data sekunder, yaitu Indonesia Family Life Survey ke-5 (IFLS5). Jumlah minimal sampel dalam sebanyak 792 orang dengan teknik total sampling dimana ditemukan sebanyak 34.012 orang yang memenuhi kriterian inklusi dan eksklusi. Analisis bivariat hubungan antara diabetes mellitus tipe 2 dan penyakit ginjal kronis dalam penelitian ini. Penelitian ini menunjukkan prevalensi penyakit ginjal kronis pada populasi Indonesia pada tahun 2014 - 2015 adalah 1\%. Hasil uji chi-square dari hubungan antara diabetes mellitus tipe 2 dan penyakit ginjal kronis pada penduduk Indonesia menunjukkan POR $=2,48(p$ value $=0,0002 ; 95 \%$ CI 1,422-4,071). ). Analisis multivariat dengan uji regresi logistik dihasilkan POR 1,88 (95\% CI 1,124-3,168; $p$ value $=0,016$ ) setelah status merokok dan riwayat kolesterol tinggi dikontrol. Penderita diabetes melitus tipe 2 diharapkan melakukan upaya pengobatan yang tepat untuk mencegah komplikasi penyakit ginjal kronis

Kata Kunci: Penyakit ginjal kronis, diabetes melitus tipe 2, IFLS5, Indonesia

\section{Introduction}

Chronic kidney disease is a structural or functional abnormality of the kidney for 3 months manifestation by kidney damage (pathological abnormalities, signs of kidney damage in urine or blood, or imaging abnormalities) or a GFR value $<60 \mathrm{~mL} / \mathrm{min}$ $/ 1.73 \mathrm{~m}^{2}$ (with or without damage kidney). ${ }^{1}$ The Global Burden of Disease research in 2010 reveal that cases of chronic kidney disease increase and became a serious health problem. Chronic kidney disease is the 27 th leading cause of death in the world in 1990 and increases to 18 th in $2010 .^{2}$ Indonesia Basic Health
A B S T R A C T

The Global Burden of Disease research in 2010 reveal that cases of chronic kidney disease increase and became a serious health problem. Indonesia Basic Health Research data in 2013 reveal that the proportion of patients with chronic kidney failure aged $\geq 15$ years old based on doctor's diagnosis was $0,2 \%$ and $0,6 \%$ kidney stones. The study aimed to analyze the relationship between type 2 diabetes mellitus and chronic kidney disease in the population of Indonesia in 2014-2015. This design of research used cross-sectional and secondary data from the Indonesia Family Life Survey (IFLS) 5. The minimum sample size in this study was 792 people with technique used total sampling, which found 34,012 people who meet the inclusion and exclusion criteria. The prevalence of chronic kidney disease in Indonesia population in $2014-2015$ was $1 \%$. The result of chi-square test of the relationship between type 2 diabetes mellitus and chronic kidney disease in the Indonesian population showed POR=2.48 (95\%CI $1.422-4.071$; $p$-value $=0.0002$ ). Multivariate analysis with logistic regression tests POR 1.88 (95\% CI $1.124-3.168$; p-value $=$ $0.016)$ after smoking status and history of high cholesterol were controlled. Patients with type 2 diabetes mellitus expects to make appropriate treatment efforts to prevent complications of chronic kidney disease.

Key words: chronic kidney disease, type 2 diabetes mellitus, IFLS-5, Indonesia

Research data in 2013 reveal that the proportion of patients with chronic kidney failure age $\geq 15$ years base on doctor's diagnosis is $0.2 \%$ and $0.6 \%$ live from kidney stones. ${ }^{3}$ IFLS5 data (5th Indonesia Family Life Survey) shows a greater proportion of chronic kidney disease, which is $1 \%$, or 1 out of 100 Indonesians suffer from chronic kidney disease.

The most common cause of CKD is diabetes. ${ }^{4}$ Diabetes mellitus (DM) is a chronic disease that requires good glycemic control and strategies to reduce risk factors. A kidney is an organ in the body that is potentially

*Corresponding: Tri Damayanti Simanjuntak. Magister Prodi Epidemiologi Fakultas Kesehatan Masyarakat Universitas Indonesia. Email: damayantitri11@gmail.com 
affected by diabetes mellitus. Globally, the percentage of type 2 diabetes is greater than $90 \% .^{5}$ The prevalence of some degree of CKD among adults with type 2 diabetes is $40 \%{ }^{4}$ Until now, research on the relationship between diabetes mellitus and kidney disease with IFLS5 data has never been done so the reserchers are interested in this topic.

\section{Method}

This research used a cross-sectional study design and secondary data, namely the 5th Indonesia Family Life Survey (IFLS 5). IFLS is an on-going longitudinal survey. The population in IFLS5 was same as in IFLS1, all households in 13 provinces in Indonesia. ${ }^{6}$ The minimum sample size in this study was used to hypothesis testing for difference two proportions. ${ }^{7}$ For study type 2 diabetes mellitus and chronic kidney disease in the Indonesian population, minimum sample size was 792 people for 2 proportions. ${ }^{8,9}$ The sampling technique in this study used total sampling in which found as many as 34,012 people who meeted the inclusion and exclusion criteria will be included as a sample. The inclusion criteria of respondents were all residents in Indonesia, both living in urban and rural areas. Respondents were excluded if they were diagnosed with kidney disease before being diagnosed with diabetes mellitus, history of hypertension, and history of high cholesterol. This was to ensure exposure occurs before the outcome. Besides, respondents who had missing data would be excluded from this study.

The independent variable was type 2 diabetes mellitus (T2DM). The categorization of type 2 diabetes mellitus was divided into yes T2DM and non-T2DM. Type 2 diabetes mellitus if ever diagnosed by health workers (doctor, paramedic, nurse, or midwives ) had diabetes mellitus and was diagnosed with diabetes when they are $\geq 30$ years old. ${ }^{10,11}$ Whereas non-T2DM, if it had never been diagnosed with diabetes mellitus during life until the study was conducted. Also, those who answered did not know, had missing data and were diagnosed at age $<30$ years were excluded from the study sample. Diagnosed T2DM was self-reported by the respondent, so the laboratorium diagnosis conducted can vary among them could be HbA1c, random blood sugar, and fasting blood sugar. The dependent variable in this study was the occurrence of chronic kidney disease. Chronic kidney disease (CKD) was divided into chronic kidney disease and nonchronic kidney disease. It was chronic kidney disease if it had been diagnosed by a healthcare provider (doctor, paramedic, nurse, or midwives) and kidney disease duration $\geq 1$ year. ${ }^{12,13}$ It was non-CKD if the patients had never been diagnosed with kidney disease until the study was conducted. Those who answered did not know, had missing data, and were diagnosed with kidney disease $<1$ year, would be excluded from the study sample. The covariate variables in this study were age, sex, smoking status, history of hypertension, and history of high cholesterol (total or Low-Density Lipoprotein/LDL). Data analyzed using univariate, bivariate, and multivariate. The magnitude of risk in the bivariate analysis was measured through the prevalence odds ratio (POR) and analyzed using chisquare with $95 \%$ confidence intervals. Multivariate analysis was performed by the logistic regression test. No ethical issue in this research because secondary data was using pseudonyms or replacements can protect the subject's identity.

\section{Result}

Out of 34,012 respondents, $1 \%$ had chronic kidney disease, $2.1 \%$ had type 2 diabetes mellitus, $3.92 \%$ had a history of high cholesterol and $12.04 \%$ had a history of hypertension. The proportions of respondents in this study were mostly female (52.34\%), aged less than 60 years (88.44\%), and non-smokers (63.31\%).

In table 1 , it presented that type 2 diabetes mellitus variable had a significant relationship with chronic kidney disease. Respondents with type 2 diabetes mellitus had a 2.48 times greater risk of having chronic kidney disease compared to respondents without type 2 diabetes mellitus. Other variables that might become potential confounders in this study were gender, smoking status, history of high cholesterol, and history of hypertension. The results of a multivariate analysis used logistic regression tests was presented in Table 2. Respondents with type 2 diabetes mellitus had a 1.74 times greater risk to suffer from chronic kidney disease compared those without type 2 diabetes after age, sex, smoking status, history of high cholesterol, and history of hypertension were controlled.

The interaction test between the main independent variables (type 2 diabetes mellitus) and the covariate variables (age, sex, smoking status, history of high cholesterol, and history of hypertension) on chronic kidney disease was presented in Table 3. From table 3, there was no interaction variable on the relationship between type 2 diabetes mellitus and chronic kidney disease in the Indonesian population because $\mathrm{p}$-value $>0.05$. Next, to 
Table 1. Bivariate Analysis to Identify The Relationship of Independent Variables, Covariate Variables to The Dependent Variable

\begin{tabular}{|c|c|c|c|c|c|c|c|c|}
\hline \multirow{3}{*}{ Variable } & \multicolumn{4}{|c|}{ Chronic Kidney Disease } & \multirow{3}{*}{ Total } & \multirow{3}{*}{ POR } & \multirow{3}{*}{$95 \% \mathrm{CI}$} & \multirow{3}{*}{ p-value } \\
\hline & \multicolumn{2}{|c|}{ Yes (n=341) } & \multicolumn{2}{|c|}{ Non $(n=33671)$} & & & & \\
\hline & $\mathbf{N}$ & $\%$ & n & $\%$ & & & & \\
\hline \multicolumn{9}{|c|}{ Type 2 Diabetes Mellitus } \\
\hline Yes & 17 & 2.38 & 696 & 97.62 & 713 & 2.48 & $1.422-4.071$ & 0.0002 \\
\hline Non & 324 & 0.97 & 32975 & 99.03 & 33348 & 1.00 & Reference & \\
\hline \multicolumn{9}{|c|}{ Age $($ mean $=38 ; \mathrm{SD}=16.05)$} \\
\hline$=60$ years old & 47 & 1.20 & 3884 & 98.80 & 3931 & 1.18 & $0.879-1.676$ & $0.1964^{*}$ \\
\hline$<60$ years old & 294 & 0.98 & 29787 & 99.02 & 30081 & 1.00 & Reference & \\
\hline \multicolumn{9}{|l|}{ Gender } \\
\hline Man & 201 & 1.24 & 16010 & 98.76 & 16211 & 1.58 & $1.268-1.981$ & $<0.0001$ \\
\hline Women & 140 & 0.79 & 17687 & 99.06 & 17801 & 1.00 & Reference & \\
\hline \multicolumn{9}{|l|}{ Smoking status } \\
\hline Smoker & 131 & 1.21 & 10697 & 98.79 & 10825 & 1.51 & $1.203-1.900$ & $<0.0001$ \\
\hline Ex-smoker & 37 & 2.24 & 1617 & 97.76 & 1654 & 2.84 & $1.974-4.043$ & \\
\hline Non smoker & 173 & 0.80 & 21360 & 92.20 & 21533 & 1.00 & Reference & \\
\hline \multicolumn{9}{|c|}{ History of high cholesterol } \\
\hline Yes & 29 & 2.18 & 1303 & 97.82 & 1332 & 2.31 & $1.51-3.398$ & $<0.0001$ \\
\hline No & 312 & 0.95 & 32368 & 99.05 & 32680 & 1.00 & Reference & \\
\hline \multicolumn{9}{|c|}{ History of hypertension } \\
\hline Yes & 61 & 1.49 & 4034 & 98.51 & 4095 & 1.60 & $1.191-2.123$ & 0.0009 \\
\hline No & 280 & 0.94 & 29637 & 99.06 & 29917 & 1.00 & Reference & \\
\hline
\end{tabular}

Table 2. Full Model Relationship between Type 2 Diabetes Mellitus and Chronic Kidney Disease, In Indonesian Population In 2014-2015

\begin{tabular}{|c|c|c|c|}
\hline Variable & POR & $95 \% \mathrm{CI}$ & p-value \\
\hline Type 2 Diabetes & 1.74 & $(1.029-2.941)$ & 0.039 \\
\hline \multicolumn{4}{|l|}{ Mellitus } \\
\hline Age & 0.96 & $(0.697-1.341)$ & 0.840 \\
\hline Gender & 1.26 & $(0.923-1.733)$ & 0.143 \\
\hline \multicolumn{4}{|l|}{ Smoking status } \\
\hline Smoker & 1.33 & $(0.965-1.839)$ & 0.000 \\
\hline Ex-smoker & 2.17 & $(1.422-3.336)$ & 0.081 \\
\hline $\begin{array}{l}\text { History of high } \\
\text { cholesterol }\end{array}$ & 1.84 & $(1.219-2.792)$ & 0.004 \\
\hline $\begin{array}{l}\text { History of } \\
\text { hypertension }\end{array}$ & 1.41 & $(1.039-1.910)$ & 0.027 \\
\hline
\end{tabular}

Table 3. Interaction Test between Type 2 Diabetes Mellitus and Covariate Variable with Chronic Kidney Disease, In Indonesian Population, In 2014-2015

\begin{tabular}{lcc}
\hline \multicolumn{1}{c}{ Variable Interactions } & p-value & Remarks \\
\hline Type 2 diabetes mellitus*age & 0.132 & Not an interaction \\
Type 2 diabetes mellitus*gender & 0.595 & Not an interaction \\
$\begin{array}{l}\text { Type } 2 \text { diabetes mellitus* status } \\
\text { smoking }\end{array}$ & 0.980 & Not an interaction \\
$\begin{array}{l}\text { Type } 2 \text { diabetes mellitus*history } \\
\text { of high cholesterol }\end{array}$ & 0.335 & Not an interaction \\
$\begin{array}{l}\text { Type } 2 \text { diabetes mellitus* history } \\
\text { of hypertension }\end{array}$ & 0.787 & Not an interaction \\
\hline
\end{tabular}

evaluated whether a covariate variable was a confounder or not by calculating the difference POR between POR crude (before covariate variable l eaves the model) and POR adjusted (after covariate variable leaves the model). When the difference POR of independent variable $>10 \%$, then the variables out of the model was a confounding variable, ${ }^{[14]}$ so it should be put back in the analysis (table 4).

Table 4. Confounding Test between Type 2 Diabetes Mellitus and Covariate Variable with Chronic Kidney Disease, In Indonesian Population, In 2014-2015

\begin{tabular}{|c|c|c|c|c|}
\hline Variable & $\begin{array}{l}\text { POR } \\
\text { crude }\end{array}$ & $\begin{array}{l}\text { POR } \\
\text { adj }\end{array}$ & $\Delta \mathrm{POR} \%$ & Remarks \\
\hline Full Model & 1.74 & & & \\
\hline Without age & 1.74 & 1.73 & 0.58 & $\begin{array}{c}\text { Not } \\
\text { Confounding }\end{array}$ \\
\hline Without gender & 1.73 & 1.74 & 0.57 & $\begin{array}{c}\text { Not } \\
\text { Confounding }\end{array}$ \\
\hline $\begin{array}{l}\text { Without history of } \\
\text { hypertension }\end{array}$ & 1.74 & 1.88 & 2.28 & $\begin{array}{c}\text { Not } \\
\text { Confounding }\end{array}$ \\
\hline Without smoking status & 1.88 & 2.02 & 11.88 & Confounding \\
\hline $\begin{array}{l}\text { Without history of high } \\
\text { cholesterol }\end{array}$ & 1.88 & 2.31 & 32.82 & Confounding \\
\hline
\end{tabular}

Based on the table 4, we knew that there were 2 confounding variables in this study, namely smoking status and history of high cholesterol. Based on the results of the interaction test and confounding test, the final model obtained in this study was as follows:

Based on table 5, respondents with type 2 diabetes mellitus had a 1.88 times greater risk of having chronic kidney disease compared to respondents without type 2 diabetes mellitus after smoking status and history of high cholesterol were controlled ( $p$-value = 0.016; 95\% CI 1.124 - 3.168). 
Table 5. Final Model Relationship between Type 2 Diabetes Mellitus and Chronic Kidney Disease, In Indonesian Population, In 2014-2015

\begin{tabular}{lccc}
\hline \multicolumn{1}{c}{ Variable } & POR & 95\% CI & p-value \\
\hline $\begin{array}{l}\text { Type 2 Diabetes } \\
\text { Mellitus }\end{array}$ & 1.88 & $(1.124-3.168)$ & 0.016 \\
$\begin{array}{l}\text { Smoking status } \\
\quad \text { Smoker }\end{array}$ & 1.55 & $(1.236-1.953)$ & 0.000 \\
$\quad$ Ex-smoker & 2.61 & $(1.816-3.747)$ & 0.000 \\
$\begin{array}{l}\text { History of high } \\
\text { cholesterol }\end{array}$ & 2.03 & $(1.353-3.036)$ & 0.001 \\
\hline
\end{tabular}

\section{Discussion}

Diagnosed T2DM was self-reported by the respondent, so the laboratorium diagnosis conducted can be vary among them could be HbA1c, random blood sugar, and fasting blood sugar. Random blood sugar could not be as an ideal standar for T2DM diagnosis so the result obtained can be overestimate.

The proportion of kidney disease based on analysis of the 5th IFLS data was around 1\%, which means that 1 out of 100 people was at risk of having chronic kidney disease. The proportion of kidney disease in the 5th data IFLS was greater than the Indonesia Basic Health Research data in 2013 on chronic kidney disease and kidney stones where $0.2 \%$ and $0.6 \%$ respectively.

The bivariate analysis results in this study proved the relationship between type 2 diabetes mellitus and chronic kidney disease in the Indonesian population. Respondents with type 2 diabetes mellitus had a 2.48 times greater risk of suffering from chronic kidney disease than respondents without type 2 diabetes mellitus ( $\mathrm{p}$-value $=0.0002 ; 95 \%$ CI 1.422 4.071). The results of this study were in line with Aljabri (2019), where there was a significant relationship between type 2 diabetes mellitus and chronic kidney disease $(\mathrm{p}<0.0001) .{ }^{15}$

Multivariate analysis proved that the relationship of type 2 diabetes mellitus and chronic kidney disease in the Indonesian population was influenced by smoking status, and history of high cholesterol. Respondents with type 2 diabetes mellitus had a 1.88 times greater risk of having chronic kidney disease compared to respondents without type 2 diabetes mellitus after smoking status and history of high cholesterol were controlled ( $p$-value $=0.016$; 95\% CI $1.124-3.168$ ). The results of this study were in line with Adebamowo(2016), where there was an impaired kidney function among those with type 2 diabetes was 1.50 (95\% CI: 1.17-1.91; p-value = 0.001) compared to those without type 2 diabetes after controlled age, sex, hypertension, BMI, and lipid (HDLc, LDLc, and triglycerides). Impaired kidney function in this research used eGFR measurement at a onetime point as to diagnosted criteria for CKD. ${ }^{16}$

Diabetes at all stages affects the kidneys. In early diabetes, the pathogenesis of glomerular hyperfiltration is well known a maladaptive response that initiating and sustaining the development of kidney damage during developing diabetes which is a joint effect of hemodynamic, vasoactive, metabolic, tubular, and pro-growth actions. At the glomerular level, there will be an increase in the plasma flow rate and hydraulic pressure in the glomerular capillaries associated with changes in systemic arterial pressure and efferent/ afferent arteriolar resistance. Hyperfiltration in diabetic patients would irreversibly injure some glomeruli which change blood flow to nephrons which function and even accelerate the rate of filtration in other glomeruli which worsens the loss of nephrons, hypofiltration, and ESRD. ${ }^{17}$ In people with diabetes mellitus whose blood sugar that is not well controlled, the endothelial wall that is an insulator between blood and tissue is easily damaged, triggering the leakage of capillaries, broken embankments, and protein get into the urine. After that, there would be symptoms of kidney damage. ${ }^{18}$

Kidney filter damage arises due to high blood sugar levels (generally above $200 \mathrm{mg} / \mathrm{dl}$ ), diabetes that lasts for years, and is exacerbated by high blood pressure (systolic lood pressure more than $130 \mathrm{mmHg}$ and diastolic above $80 \mathrm{mmHg}$ ). The longer they had diabetes, the longer high blood pressure lasts, and the easier the kidneys to get damaged. ${ }^{18}$ Smoking also had a connection with the occurrenced of complications in people with diabetes. A common complication in people with diabetes who smoke is kidney disease, which is referred to as nephropathy, which increases the risk of albuminuria. ${ }^{19}$ The toxic content of cigarettes would be poisoning the entire body. Cigarettes can damage the kidneys both directly and indirectly. Cigarettes increase blood pressure, which worsens the kidneys. Nicotine and smoking are very bad for the blood vessels of the kidneys filter and increase the tendency to leak. ${ }^{18}$ Besides, aging coupled with chronic diseases, such as high blood pressure (hypertension) or diabetes, are likely to cause irreversible kidney damage. Sugar poisoning due to diabetes will cause nephron damage, which is called diabetic nephropathy. Many diabetics often lowers HDL cholesterol, high triglyceride, and high LDL cholesterol. The target LDL cholesterol in adult diabetics is less than $100 \mathrm{mg} / \mathrm{dl}$, lower is better. A 
greater LDL value might be acceptable for someone without diabetes, but it is too high for many diabetics. High blood sugar associated with diabetes can accelerate changes in a chemical known as LDL cholesterol oxidation. The oxidation of LDL cholesterol plays a role in causing inflammatory damage and causes atherosclerosis. And the buildup of atherosclerosis in the kidneys can cause chronic kidney disease. $^{20}$

\section{Conclusions}

The results of this study prove there is a relationship between type 2 diabetes mellitus and chronic kidney disease in the Indonesian population. Multivariate analysis with logistic regression tests POR $1.88(95 \%$ CI 1.124 - 3.168; p-value $=0.016)$ after controlling smoking status and history of high cholesterol. Respondents with type 2 diabetes mellitus have a 1.88 times greater risk of having chronic kidney disease compare to respondents without type 2 diabetes mellitus after controlling smoking status and history of high cholesterol. The relationship influence by smoking status and history of high cholesterol. Patients with type 2 diabetes mellitus expects to make appropriate treatment efforts to prevent complications of chronic kidney disease. Whereas for those without type 2 diabetes mellitus, they expect to make prevention efforts by implementing a healthy lifestyle by not smoking and controlling the consumption of food which triggers an increase in cholesterol in the blood which can ultimately lead to chronic kidney disease. Besides, it expects from health facilities to give proper education to people with type 2 diabetes mellitus to prevent chronic kidney disease.

\section{Acknowledgments}

The authors would like to thank the RAND team who conducted the IFLS survey who provided the data set. The full report from IFLS5 is available for download at https://www.rand.org/well-being/socialand-behavioral-policy/data/FLS/IFLS.html

\section{Reference}

1. Reuntens AT, Alkins RC. Chronic kidney disease (CKD): the scope of the global problem. In: Nahas M El, Levin A, editors. Chronic Kidney Disease/: A Practical guide to understanding and managemment. UK: Oxford University Press; 2010.

2. Kemenkes RI. Ginjal Kronis [Internet]. Kementeri. Kesehat. Republik Indones.2017 [cited 2020 May 31];Available from: http://p2ptm.kemkes.go.id/kegiatan-p2ptm/subditpenyakit-jantung-dan-pembuluh-darah/ginjal-kronis
3. Kemenkes RI. Pokok-Pokok hasil Riskesdas Indonesia 2013 [Internet]. 2013 [cited 2020 May 31]. Available from: http:/ /kesga.kemkes.go.id/images/pedoman/Pokok Pokok Hasil Riskesdas Indonesia 2013.pdf

4. Pyram R, Kansara A, Banerji MA, Loney-Hutchinson L. Chronic kidney disease and diabetes. Maturitas [Internet] 2012 [cited 2020 Aug 21];71(2):94-103. Available from: http://dx.doi.org/10.1016/j.maturitas.2011.11.009

5. Zimmet P, Cameron A, Shaw J. The Diabetes Epidemic: Genes and Environment Clashing. In: Ganz M, editor. Prevention of Type 2 Diabetes. England: John Wiley \& Sons, Ltd; 2005.

6. Rand. RAND IFLS-5 Survey Description [Internet]. 2016 [cited 2020 May 29];Available from: https://www.rand.org/ well-being/social-and-behavioral-policy/data/FLS/IFLS/ ifls5.html

7. Kelsey JL, Whittemore AS, Thompson ASEWD. METHODS IN OBSERVATIONAL EPIDEMIOLOGY. Second Edi. New York: Oxford University Press; 1996.

8. Faye M, Lemrabott AT, Cissé MM, Fall K, Keita Y, Ngaide AA, et al. Prevalence and Risk Factors of Chronic Kidney Disease in an African Semi-urban Area: Results from a Crosssectional Survey in Gueoul, Senegal. Saudi J Kidney Dis Transplantation 2017;28(6):1389-96.

9. González AO, de Francisco A, Gayoso P, García F. Prevalence of chronic renal disease in Spain: Results of the EPIRCE study. Nefrologia 2010;30(1):78-86.

10. Anggota IKAPI. Agar Pankreas Sehat Jakarta: PT Elex Media Komputindo; 2012.

11. Kahn CR, Weir GC, King GL, Jacobson AM, Moses AC, Smith RJ. Diabetes Melitus. Fourth Edi. Boston: Joslin Diabetes Center; 2005.

12. Susianti H. Memahami Interpretasi Pemeriksaan Laboratorium Penyakit Ginjal Kronis. Malang: UB Press; 2019.

13. Marcus A, Wang W. Design, User Experience, Usability/ : Apllication Domain. Switzerland: Springer; 2019.

14. Kleinbaum DG, Klein M. Logistic Regression A SelfLearning Text Second Edition. New York: Springer-Verlag New York; 2002.

15. Aljabri K. Serum lipid profiles in patients with chronic kidney disease in a Saudi population. Endocrinol Int J 2019;7(1):41-6.

16. Adebamowo SN, Adeyemo AA, Tekola-Ayele F, Doumatey AP, Bentley AR, Chen G, et al. Impact of type 2 diabetes on impaired kidney function in sub-saharan African populations. Front Endocrinol (Lausanne) 2016;7(MAY):16.

17. Wang Y, Zhong B, Li Y, Qin X, Wang B, Xu X, etal. Relationship of diabetes with renal dysfunction in hypertensive adults. Medicine (Baltimore) 2017;96(24):1-6.

18. Tandra H. Dari Diabetes Menuju Ginjal. Jakarta: PT Gramedia Pustaka Utama; 2018.

19. Marewa LW. Kencing Manis (Diabetes Melitus) di Sulawesi Selatan. Jakarta: Pustaka Obor Indonesia; 2015.

20. Hasslacher C, Bohn S. Diabetes and the kidney. German:

John Wiley \& Sons Ltd; 2004 
Jurnal Epidemiologi Kesehatan Indonesia Vol 4. No. 2, Desember 2020 